\title{
The Effect of Geometric Puzzle Game Towards Children's Recognition of Geometric Shapes and Fine Motor
}

\author{
Yuniarini Kuspita Sari, Wahyu Sukartiningsih\& Miftakhul Jannah \\ State University of Surabaya \\ Surabaya, Indonesia \\ yuniarinikuspitasari@gmail.com
}

\begin{abstract}
The research found that the children's recognition of geometric shapes and fine motor in Group A was low. Such finding was caused by the classical method of learning applied in the classroom such as lecturing and having the children do worksheets so that the learning activities were not attractive as well as less innovative. This research aims at knowing the influence of the puzzle game about geometry towards the ability to know the geometric shapes and fine motor of older group of children. The research used was quantitative method with quasi experimental as the design with the use of non-equivalent control group design. This study involved 103 children from some kindergartens in Surabaya. The data were collected using observation sheets and documentation. The results of this study showed that the children in the experimental group showed greater ability to know the geometric shapes and fine motor compared to the children in the control group. In addition, the geometric puzzle game proved that it was an effective way to help students with the ability to know the geometric shapes and fine motor.
\end{abstract}

Keywords- geometry puzzle game; recognize geometric shapes; fine motor

\section{INTRODUCTION}

Early childhood is an individual who runs a process of fundamental development that can affect the future life (Sujiono, 2009:6). Children have different characteristics which means that one child is unique and different from the other children. The characteristics of children are always active, dynamic, enthusiastic as well as they have a high curiosity towards what is seen, heard, and what is perceived. The achievement of developments requires the giving of appropriate stimulation in order to develop appropriate developmental stages so that they are achieved optimally.

According to the government regulations of the Republic of Indonesia number 146 year 2014, there are six aspects of children development including the religious moral, cognitive, physical, social, emotional, motoric, language and art aspect. Two of the aspects covered are the cognitive and physical development of the children's motoric ability especially in recognizing geometric shapes and fine motor.

Cognitive development is one of the important developmental aspects developed in child's thinking skill.
Similar to the opinion [1] which states that cognitive development is an individual's ability in the process of thinking to connect, judge, and consider an event or events that are experienced by the child. Cognitive processes are associated with the level of intelligence (intelligentsia) that influence the children in expressing an idea, opinion or any ideas against the thought processes by them.

The aspects dealing with the child development cannot flourish individually. They are interconnected between the development of each other. Therefore, the children are able to learn through the symbolic thinking ability, solve problems. Furthermore, those aspects help the children to develop their ability of mathematical logic, knowledge of space and time, as well as preparing for the development of the ability to think carefully.

That there are four stages of cognitive development of children including the stages of the remote motor, pre operational stage, concrete operational stage, and the formal operational stage [2]. For children with age of 4-5 years, they are in the developmental stages of pre-production operations. Pre-operational stage is a stage in which the child starts building their ability to think. Children of 4-5 years old are able to describe an object concretely and it can be seen that such thing affects their ability to think logically.

Dealing with the ideal conditions of children of 4-5 years, Permendiknas RI 2014 number 137 states that the scope of the development of those children are the ability of logical thinking that is to know the geometry with the level of achievement of development deals with classifying objects according to the function, shape, color, or size. Furthermore, they start to get to know the geometric shapes by identifying some shapes such as triangle, circle, and square.

It is explained that recognizing geometric shapes is the ability of the children to know, point, mention as well as collect the objects around them based on the geometric shapes [3]. In the beginning, there should be an introduction of the geometric shapes that can be done before the children do identification. After doing the identification process, the children are able to point and then classify the objects around them which suit the shapes of the geometry that they have been learned previously.

The ability to know the geometric shapes on early childhood is very important for the children's cognitive development. The introduction to geometry increase the 
children's creativity and intellect which affect their intellectual development such as the capability of remembering. Therefore, introducing geometric shapes at the age of 4-5 years help the children distinguish and find out a variety of geometric shapes existing around them.

Cognitive development of children is the ability to know the geometric shapes which are not far from the other developmental aspects such as physical development of fine motor abilities. Motor development is the ability to control the movement of the body through the coordination of nerves, muscles and brain. Meanwhile, physical motor development deals with motor capabilities including coarse and fine.

Fine motor ability is a movement involving the members of the body. Fine motor ability of children involves the use of hands and fingers. Fine motor ability focuses on the ability of eyes and hand coordination [4].

The development of children's motor skills is affected by the brain or the child's intellectual aspects that can set any movement to be performed. It is stated as a way to support a balanced approach for early childhood education in terms of maintaining the importance of physical activity and the development of fine motor skills in connection to the cognitive aspects [5]. Those activities involve the coordination of eyehand in fine motor skills which can be associated in the aforementioned aspect.

Ideal conditions for children at 4-5 years old in the Years Permendiknas RI Number 1372014 deal with the scope of the development of those children in physical development fine motor i.e. particularly motor with coordinated eyes and hands to do certain complicated movements.

Based on the reality occurring in the field, the children lacked of the ability to know or understand geometric shapes, and the children found it difficult to pair objects according to the shape. There were also some children who has already known but still had a difficulty in distinguishing geometric shapes such as triangle and square. Meanwhile, the fine motor ability of the children in activities such as making tassel, copying and squeezing took a long time as well as they lacked of patience in doing the activities.

Fine motor ability of children long tends to deal with accomplishments rather than rugged motor since fine motor abilities require concentration and coordination of the eyes and hands. Teachers should provide learning materials with suits the attainment of children development in order to assist them in shaping the way of thinking of knowledge, as well as using various media and methods to develop the entire basic capabilities themselves. The exact activities are in accordance with the characteristics of the children in improving their learning achievement during the process of leaning.

The solution, or the problem solving, with the application of learning is by introducing fine motor and geometric shapes can be done by using the game. Playing is an activity in which kids use tools that can provide pleasure as well as develop the imagination of the children. Bermian is an activity that kids do in individual or group by using the tools to achieve certain objectives [5].

The earliest known puzzle especially geometry is mostly used because she had helped the students in developing their cognitive and physical abilities including the naming motor knows geometric shapes and fine motor. Play is very beneficial for the brain in the process of development children development. Such playing can train the children's eyes and hands coordination as well as recognize geometric shapes therough geometric puzzle game. It is a part of the puzzle game construction which is done by pairing or fixing the boxes, or picture that lead to a certain pattern for a particular shape [5].

Puzzle game can train the fingers and hand-eye coordination as well as the cognitive ability to match the right shape and the geometry objects [6]. Based on the opinions above, it can be interpreted that the media used in playing puzzle game deals with how the game goes by identifying and matching the right geometric pieces so that they are arranged into the right formation.

This puzzle game is a game that requires patience and thoroughness dealing with the shapes in geometry. Geometric puzzle game is a game which is used for learning the plywood boards made of a cube that has the earliest known four kinds different puzzles. Each of the earliest known puzzles are for developing fine motor and thinking ability.

Playing can train fine motor abilities of the child. It can be seen from the ability of the child to do activities recognize the geometric shapes. There are some benefits of puzzle game including 1) training the brain, 2) training the coordination of the eyes and hands, 3) training the thinking ability, 4) practicing patience, and 5) developing the knowledge.

Based on the background that has been presented, the researchers conducted a study entitled "The Effect of Geometric Puzzle Game Towards the Ability to Know Geometric Shapes and Fine Motor of A Group Children of one Kindergarten in Jambangan Surabaya".

\section{METHOD}

This research, dealing with the influence of geometric puzzle game towards the ability to know the geometric shapes and fine motor group A children in one kindergarten in Jambangan Surabaya, used a quantitative approach with the experimental researchas the design. It was used to know whether the students understand what they had gotten in the introduction of the material.

This research used quasi experimental design with nonequivalent control group design. In designing the experimental group and the control group, non-random sampling was used with considerations. The samples in this research involved $\mathrm{A}$ group of children in KB. RA Perwanida and Al Huda Kindergarten Surabaya in which the total number reached 103. From the explanation above, then the researchers selected samples with the total number of 103 children divided into two classes of experimental group and control group. The experimental group, in this study, consisted of two classes with the total sample of 52 children. Meanwhile, the control group consisted of two classes with the number of samples as much as 51 children. The scale used in this research was the Likert scale in which there were scale number 1-4, written with an asterisk. The use of the asterisk was a symbol to indicate the level of achievement of the children's development as recorded by the teacher.

This research used Anova and Manova as the techniques of the data analysis with the significance level $=0.05$ using SPSS program assistance 24 for windows. Such techniques were 
used in order to test the first hypothesis stating that the application of geometric puzzle game has an effect on the ability to know the geometric shapes. Meanwhile, the second hypothesis states that the application of geometric puzzle game affects the fine motor. The third hypothesis states that the application of geometric puzzle game has an effect on the children's ability to know geometric shapes and fine motor.

\section{RESULT AND DisCUSSION}

The validity testing of invalid constructions in this research was conducted with the help of two early childhood education experts (expert judgment) as the assessors. After making the validity had been reached, the instrument of knowing the ability to know the geometric shapes and fine motor was used to calculate the 'content' according to the validity using SPSS product moment correlation. Through the instrument of the validation testing, it resulted the ability of recognizing geometric shapes and fine motor of the validator are:

TABLE I. CONSTRUCT VALIDITY RESULT

\begin{tabular}{|l|c|c|}
\hline \multicolumn{1}{|c|}{ Validation Sheet } & Percentage & Category \\
\hline $\begin{array}{l}\text { The instrument of geometric } \\
\text { puzzle game (early } \\
\text { childhood education) }\end{array}$ & $90 \%$ & $\begin{array}{c}\text { Advisable to use with no } \\
\text { revision }\end{array}$ \\
\hline $\begin{array}{l}\text { The instrument of the ability } \\
\text { to know the geometric } \\
\text { shapes and fine motor (early } \\
\text { childhood education) }\end{array}$ & $100 \%$ & $\begin{array}{c}\text { Advisable to use with no } \\
\text { revision }\end{array}$ \\
\hline
\end{tabular}

TABLE II. CONTENT VALIDITY RESUlt

\begin{tabular}{|l|l|l|}
\hline \multicolumn{1}{|c|}{ Validation Sheet } & \multicolumn{1}{|c|}{ rable $_{\text {tategory }}$} & \multicolumn{1}{c|}{ Category } \\
\hline $\begin{array}{l}\text { Instrument of } \\
\text { recognizing } \\
\text { geometric shapes }\end{array}$ & $\begin{array}{l}\text { 1st item }(0,668) \\
\text { 2nd item }(0,524)\end{array}$ & $\begin{array}{l}\left(\mathrm{r}_{\text {table }}=0,290\right) . \\
\text { These instruments can be used } \\
\text { to measure the ability to know } \\
\text { the geometric shapes }\end{array}$ \\
\hline $\begin{array}{l}\text { Instrument of fine } \\
\text { motor ability }\end{array}$ & $\begin{array}{l}\text { 1st item }(0,422) \\
\text { 2nd item }(0,349) \\
\text { 3rd item }(0,350)\end{array}$ & $\begin{array}{l}\left(\mathrm{r}_{\text {table }}=0,290\right) . \\
\text { These instruments can be used } \\
\text { to measure fine motor ability }\end{array}$ \\
\hline
\end{tabular}

The results of the validity testing calculation can be seen in table I and II which indicate that the instrument was a tool that consisted of learning instrument of geometry puzzle game and scoring sheet in the form of the instrument used to reveal the ability to know the geometric shapes and fine motor. The instruments were considered valid to be used for this study.

\section{CONCLUSION}

Based on the results and discussion of the experiment, it can be concluded as some matters dealing with: (1) the cycle of learning of the geometric puzzle game towards the ability to know the geometric shapes of the A group children in one kindergarten in Jambangan Surabaya 2) the cycle of learning geometric puzzle game dealing with the fine motor ability of the group A children in one kindergarten in Jambangan Surabaya. Learning geometric puzzle game can be used as an alternative method of learning and to develop game in the aspect of children's cognitive development and fine motor, especially the ability to know the geometric shapes and A group children's fine motor in kindergarten.

\section{REFERENCES}

[1] A. Susanto, Perkembangan anak usia dini: Pengantar dari berbagai aspeknya. Jakarta: Kencana, 2011.

[2] Y. N. Sujiono, "Konsep dasar pendidikan anak usia dini," 2009.

[3] J. Piaget, Child's Conception of Space: Selected Works vol 4. Routledge, 2013.

[4] Masganti Sit, Psikologi Perkembangan Anak Usia Dini. Jakarta: Kencana, 2017.

[5] P. Bhatia, A. Davis, and E. Shamas-Brandt, "Educational gymnastics: The effectiveness of Montessori practical life activities in developing fine motor skills in kindergartners," Early Educ. Dev., vol. 26, no. 4, pp. 594-607, 2015.

[6] J. J. Beaty, Observasi perkembangan anak usia dini. 2013. 